\title{
The Analysis Of The Online Physical Education Learning During The Pandemic In The Outmost Area
}

\author{
Maharani Fatima Gandasari ${ }^{1}$, Ella Anugrarista ${ }^{2}$, Erna Yantiningsih ${ }^{3}$ \\ \{maharani.fg8@gmail.com ${ }^{1}$, ellaanugrarista@gmail.com ${ }^{2}$, ernacjdw@gmail.com ${ }^{3}$ \}
}

STKIP Pamane Talino, Indonesia ${ }^{123}$

\begin{abstract}
This study aims to identify how the online physical education learning process is during the pandemic. The design used is causal comparative (ex-post facto). The aim is to see how the learning activities and what media are used by Physical Education teachers. The instrument used was an online questionnaire with several questions, starting from the identity of the teacher, the media used, the obstacles experienced by teachers in online learning and the teacher's perceptions of online learning today. The sample used was elementary to high school physical education teachers. The results showed that the use of learning application media was obtained for elementary school physical education teachers who preferred more to use social media WhatsApp for teachers aged $<40$ years $=49 \%$, junior high school teachers aged $24-40$ years $=35.54 \%$ preferred more to use google classroom, while high school teachers who were dominated by teachers aged $24-40$ years $=34 \%$ using 3 learning application media with a small difference, namely, google classroom, Whatsapp and manual. The dominant use of applications in each educational unit cannot be denied, apart from the age factor, other things, namely, the geographical location factor and the ability of the human resources of the physical education teachers themselves.
\end{abstract}

Keywords: Online Learning, Physical Education, Learning Application Media

\section{Introduction}

The Covid-19 pandemic emerged in December 2019 has effected many sectors of human life including the education. All indoor activities are postponed to do including school activities to anticipate the spread of the Covid-19 infection, so those school indoor activities are shifted from classroom to the online learning media. Moreover, there was also the official circular letter (Cicular Letter No. 13 Education and Culture Authority 2020 about the education policy under emergency situation of Covid-19 pandemic) published by local education authority ordering "the learning process being done via online media as the alternative of learning media" [1] explains that "there are two learning models which can be used by teachers as the media of learning to deliver the knowledge, namely, online and mixed or blended learning model (the combination of two learning methods online and offline learning)". Under this circumstance, the government has given the freedom to each school and also the teachers in that institution to choose and use the online learning platform to apply in their classrooms. The ministry of education also provides two free online learning platforms named "Rumah Belajar" and "Program Guru Berbagi". Those free platforms give several 
benefits to the users where Rumah Belajar gives and provides the learning materials and the other additional features possibly being accessed by the users. The platform Berbagi antar Guru enables teachers to share the lesson plans among the teachers across the country. According to Ismail, the learning process cannot be separated from the important role of the teacher and students to achieve the better leaning process. Therefore, lesson planning is the main key of teacher's effort to prepare the learning activity. Through the learning combination model, teachers and students will always continue the application of technology which is combined by the face-to-face method to have a comprehensive learning practice. The internet connection, smartphone, and laptop which become the part of the current technology have been widely used whereas the users make use of them to do the distance learning. Nadia states that "based on the Indonesian topography characterized by archipelagic and mountainous area, it needs the widespread accessible cellular service where, factually, there are still so many areas which have not yet received the internet connection service so that condition causes the online learning still difficult to maximally" [2]. "The another factor is the lack of fast and reliable technology and internet access for the students living in the rural area and in the low class family" [3]. This type of learning makes use of the internet technology equipped with the accessibility, connectivity, flexibility, and ability enabled the learning interaction variety in a virtual classroom [4]. "The fact in the field, based on the explanation from Titis Ekawati quoted by Antara, shows that the characteristic of area in Sanggau varies from one place to the other and not all area are available with internet connection"[5]. According to [6], there are some obstacles faced by the physical education teachers in the process of virtual learning application; "(1) Not all physical education teachers and students have the access to the computer, laptop, and smartphones. (2) there are some teachers who are not skillful yet to make use of the learning media both hardware and software; (3) the internet access is still limited in most of area where the teachers work; (4) the physical education teachers are mostly confused to choose the learning platform that can facilitate the physical education".

There are several factors which should be considered so that the distance learning can be done well. Those factors are the attention, teacher's confidence, experience, ability and creativity to use the supporting devices and ability to create an interaction to the students. The distance learning is attributed by the benefits of location and time flexibility. The school staffs, teachers, and students struggle adapting to the new model of online learning [7]. Under this circumstance, the teachers and students, not only in Indonesia but also the other countries all over the world, have been practicing the online learning to solve the problems of the absence of face-to-face learning caused by the pandemic. The other benefits of the online learning media are "the high level of outonomy and interaction in learning, the improvement of memorizing ability, the wider range of learning experience through the use of texts, audios, videos and animation being used to deliver the information, and also an easy access to updating the content, downloading, e-mailing among students, sending comments in discussion forum, using chat room, and having teleconference for a direct communication" [8]. "The obstacles or issues faced in the process of distance learning are founded in the field. Based on the preliminary survey done by Pustekkom team, there were several reports about the common problems faced in the outmost location area which were related to information and 
computer technology issues. Those problems were 1) the absence of the electricity, 2) the absence of internet connection, 3) the absence of internet and computer infrastructure, 4) the absence of human resource to information technology, 5) the bad or even absence cellular in several areas" [9]. The ICT skill of teachers in Indonesia is not distributed equally in all areas. The big gap of Indonesian education quality is also one of the obstacles. The other factors are the internet access, the teacher qualification, education quality, and the lack of ICT skill causing the problems in the distance learning initiative.

The implementation of the online learning in the field requires the readiness both the education providers, teachers, and the participants, students [10]. The online learning has been already done by some teachers in several areas in Kalimantan, especially, Landak Regency, West Kalimantan. Nevertheless, the reality shows that the online learning does not run well. There are some schools in the outmost area near the border between Indonesia and Serawak, Malaysia. The observation of the online learning in those areas could not be done because those areas are not provided with the internet connection. That situation also happened in physical education subject [11]. It may be difficult to imagine how the online learning is implemented in physical education subject. Moreover, physical education subject requires the physical activities in its learning process. This research is conducted based on the statements presented previously where the aim is to search for the information on how physical education learning should be designed online during the pandemic and also about how teachers choose the learning media, materials, and identify the problems in the learning process.

\section{Method}

In the qualitative research, the validity of the data depends on the source and techniques to collect the data [12]. The researcher collected data from the result of the survey where the data was collected and proceeded in MS Excel spreadsheet. The statistical presentation is originally the result of some statements characterized by general quantitative. The design applied in this research was causal comparative (ex-post facto) which was aimed to observe what the learning media and activities applied by physical education teachers during the pandemic. The questionnaire was used as the instrument of the research spread by online. the questionnaire consisted of several questions about personal information of the teachers (name, gender, degree, age) and learning media used in their online learning classes. In this research, the validity testing to the instrument of the research was conducted through bivariate Pearson (Pearson correlation product moment). The method was conducted by correlating each item score with the item total score. The item correlative coefficient with Pearson bivariate can be identified with the following formula:

$$
\begin{aligned}
& \mathrm{r}=\frac{n \Sigma i x-(\Sigma i)(\Sigma x)}{\left.\sqrt{\left[n \Sigma i^{2}\right.}-(\Sigma i)^{2}\right]\left[n \Sigma x^{2}-(\Sigma x)^{2}\right]} \\
& \text { where : } \\
& \mathrm{r}: \text { the coefficient of total item correlation }
\end{aligned}
$$


I : score of item

$\mathrm{x}$ : total score

$\mathrm{n}$ : number of subject (Priyatno, 2010:91)

The instrument validity testing was conducted toward 200 respondents ouside the targeted sample but it still represented the population characteristic. To determine the validity of the items, it was based on the number of respondents and $r$ table value at $5 \%$ significance level, namely, 0.361 . It means that the item is categorized as valid item if its $t$ count is larger than t table, 0.361 . The result of the testing is presented in the following table:

Table 1.Validity Testing of Variable X

\begin{tabular}{|c|c|c|c|}
\hline Item & $\begin{array}{l}\text { Corrected } \\
\text { Item- Total } \\
\text { Correlation }\end{array}$ & $\begin{array}{c}\text { Critical } \\
\text { limit }\end{array}$ & Status \\
\hline P1 & 0,466 & 0,361 & Valid \\
\hline P2 & 0,545 & 0,361 & Valid \\
\hline P3 & 0,403 & 0,361 & Valid \\
\hline $\mathrm{P} 4$ & 0,646 & 0,361 & Valid \\
\hline P5 & 0,681 & 0,361 & Valid \\
\hline P6 & 0,708 & 0,361 & Valid \\
\hline P7 & 0,590 & 0,361 & Valid \\
\hline P8 & 0,469 & 0,361 & Valid \\
\hline P9 & 0,612 & 0,361 & Valid \\
\hline $\mathrm{P} 10$ & $0,6,99$ & 0,361 & Valid \\
\hline P11 & 0,540 & 0,361 & Valid \\
\hline $\mathrm{P} 12$ & 0,640 & 0,361 & Valid \\
\hline P13 & 0,666 & 0,361 & Valid \\
\hline $\mathrm{P} 14$ & 0,496 & 0,361 & Valid \\
\hline $\mathrm{P} 15$ & 0,545 & 0,361 & Valid \\
\hline P16 & 0,432 & 0,361 & Valid \\
\hline P17 & 0,683 & 0,361 & Valid \\
\hline P18 & 0,418 & 0,361 & Valid \\
\hline P19 & 0,393 & 0,361 & Valid \\
\hline $\mathrm{P} 20$ & 0,553 & 0,361 & Valid \\
\hline P21 & 0,543 & 0,361 & Valid \\
\hline P22 & 0,585 & 0,361 & Valid \\
\hline P23 & 0,638 & 0,361 & Valid \\
\hline P24 & 0,559 & 0,361 & Valid \\
\hline
\end{tabular}

The result of validity testing of variable $\mathrm{X}$ (the obstacles in the online learning) shows that all 24 question items for variable $X$ are valid because of the corrected item-total correlation larger than 0.361 .

Table 2.Validity Testing of Variable Y

\begin{tabular}{l|l|l|l} 
Item & Corrected & Critical & Status \\
\hline
\end{tabular}




\begin{tabular}{|c|c|c|c|}
\hline & $\begin{array}{c}\text { Item- Total } \\
\text { Correlation }\end{array}$ & limit & \\
\hline P1 & 0,674 & 0,361 & Valid \\
\hline P2 & 0,713 & 0,361 & Valid \\
\hline P3 & 0,664 & 0,361 & Valid \\
\hline P4 & 0,681 & 0,361 & Valid \\
\hline P5 & 0,457 & 0,361 & Valid \\
\hline P6 & 0,366 & 0,361 & Valid \\
\hline P7 & 0,565 & 0,361 & Valid \\
\hline P8 & 0,469 & 0,361 & Valid \\
\hline P9 & 0,447 & 0,361 & Valid \\
\hline P10 & 0,598 & 0,361 & Valid \\
\hline P11 & 0,833 & 0,361 & Valid \\
\hline P12 & 0,498 & 0,361 & Valid \\
\hline P13 & 0,806 & 0,361 & Valid \\
\hline P14 & 0,366 & 0,361 & Valid \\
\hline P15 & 0,603 & 0,361 & Valid \\
\hline P16 & 0,713 & 0,361 & Valid \\
\hline P17 & 0,664 & 0,361 & Valid \\
\hline P18 & 0,477 & 0,361 & Valid \\
\hline P19 & 0,833 & 0,361 & Valid \\
\hline P20 & 0,498 & 0,361 & Valid \\
\hline P21 & 0,498 & 0,361 & Valid \\
\hline P22 & 0,806 & 0,361 & Valid \\
\hline P23 & 0,457 & 0,361 & Valid \\
\hline P24 & 0,366 & 0,361 & Valid \\
\hline & & & \\
\hline
\end{tabular}

Simillar to the previous validity testing toward variable $X$, the validity testing toward variable $\mathrm{Y}$ also shows that 24 items for variable $\mathrm{Y}$ are also valid because the corrected item-total correlation is larger than 0.361 . Reliability relates to the trustworthy toward the test instrument. The reliability requires the stability between the observation and the instrument. There some primary steps in analysing the reliability, namely: a) Adding the score of even numbered question (x) and odd numbered question $(y), b)$ Identifiying the product moment coefficient rxy between $x$ and y, c)Correcting r xy using Spearman Brown formula.

Those steps were applied to measure the level of reliability of the instrument for variable $\mathrm{X}$ and $\mathrm{Y}$. The application used to do the mesurement was SPSS for Windows Release 16. The reliability testing toward the instriment involved 200 respondents. The result of the test is presented in the following table:

Table 3 The Result Of Instrument Reliabilty Testing

\begin{tabular}{ccccc}
\hline Variable & Item & $\begin{array}{c}\text { Score-Total } \\
\text { Correlation }\end{array}$ & Sig. (2- tailed) & Status \\
\hline $\mathrm{X}$ & 24 & $0.861^{* *}$ & 0,000 & Reliable \\
$\mathrm{Y}$ & 24 & $0.831^{* *}$ & 0,000 & Reliable \\
\hline
\end{tabular}

Based on the Score-Total correlation in the table, the result shows that both instrument score for variable $\mathrm{X}$ and $\mathrm{Y}$ are 0.861 . It shows that those instruments have a high level of correlation or they are all reliable. It is chracterized by the sign of stars 
on the Score-Total Correlation. The sample of the research was the teachers in the Landak regency from the elementary to the senior high school level. The number of the sample in each eaducational level or unit is presented in the following table.

Table 4. Physical Education Teacher Respondents in Landak Regency

\begin{tabular}{cc}
\hline Educational Unit & Respondents \\
\hline Elementary school & 50 \\
Junior high school & 40 \\
Senior high school & 110 \\
\hline Total & 200 \\
\hline
\end{tabular}

\section{Result and Discussion}

The conclusion from the previous statements is that the physical education teachers of elementary school in Landak Regency during the pandemic used Whatsapp application (35.0\%), google classroom (25\%) and manual learning $(40 \%)$ where they were used by teachers aged from $24-40$. The users of whatsapp were $39.0 \%$ and $50 \%$ of teachers aged 40 . It can be concluded that the users of google classroom are still rare if it is contrasted to the users of Whatsapp where they consider the application easier to be used and accessed. Moreover, there are many teachers who still had the manual or offline learning caused by the presence of internet connection and devices (smartphone, laptop and etc.) to use in that area. This research is purposed to identify on how the physical education learning activity is done during the pandemic. That research was done through the review from the learning media used by the physical education teachers. The population of the research are physical education teachers of elementary school (50 respondents), junior high school (38 respondents), and senior high school (36 respondents). The total is 128 respondents in Landak Regency. The researcher used the interview, questionnaire and document as the technique of data collection. The research was conducted from September to December 2020. The data and its analysis from the questionnaire of this research to the physical learning during the pandemic are presented.

Table 5. The age description of elementary, junior and senior high school in Landak Regency

\begin{tabular}{cccc}
\hline Educational Unit & Age & Frequency & Percentage (\%) \\
\hline \multirow{2}{*}{ Elementary school } & $24-40$ & 23 & $23,00 \%$ \\
& $>40$ & 30 & $30,00 \%$ \\
Junior high school & $24-40$ & 20 & $20,00 \%$ \\
& $>40$ & 6 & $6,00 \%$ \\
Senior high school & $24-40$ & 24 & $24,00 \%$ \\
& $>40$ & 7 & $7,00 \%$ \\
& & 100 & $100 \%$ \\
\hline
\end{tabular}




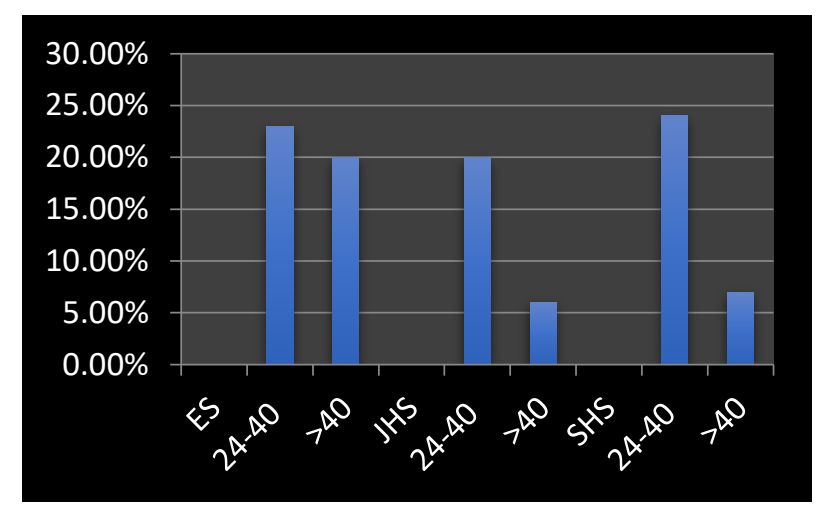

Diagram 1. Picture based on the age

Based on the diagram above, it can be identified that the age percentage for elementary school teachers is that the lowest age is 40 years old above with the percentage $20.00 \%$ while the range of the age $24-40$ years old, the percentage is $23 \%$. The age percentage for junior high school teachers is that the lowest is 40 years old above $6.00 \%$ while the age 24 40 is $20.00 \%$. The age percentage for senior high school teachers is that the lowest is 40 years old above $7.00 \%$ while the age $24-40$ is $24 \%$. That means that the age of teachers in Landak Regency is mostly categorized in the age between 24-40. That range of age is a productive age where the young teachers can update and develop the education in the future. At the moment, teachers should always challenge themselves to develop and be creative in facing the change and technology development. Creativity and innovation can help teachers to encounter the global issues. The teachers' unpreparedness in facing the pandemic is so unfortunate because they have to do the online learning. There are several issues faced by teachers and students in the online learning identified from the result of the questionnaire. Researcher has analyzed the preparation of schools, teachers and students to do the online learning during the pandemic [13]. Below is the questionnaire analysis of learning media applications which are used by teachers in Landak Regency.

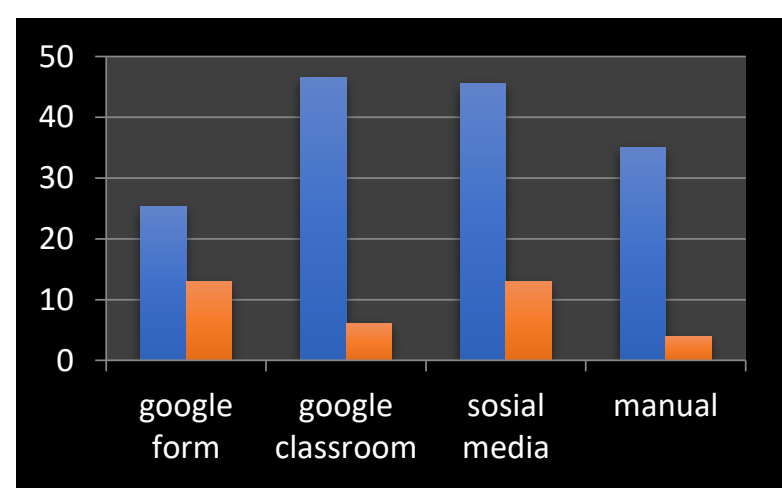

Diagram 2. The use of learning media application in Elementary School 
Based on the diagram above, there are 5\% teachers using Google Form, $2.5 \%$ Google Classroom, $85.0 \%$ Wahatsapp application and $7.5 \%$ using the manual method. This information was collected through questionnaire filled by every teacher in the elementary school. So, it can be concluded that the use of application media by junior high school teachers puts Whatsapp with the highest percentage of use $85.0 \%$ and the manual method follows after.

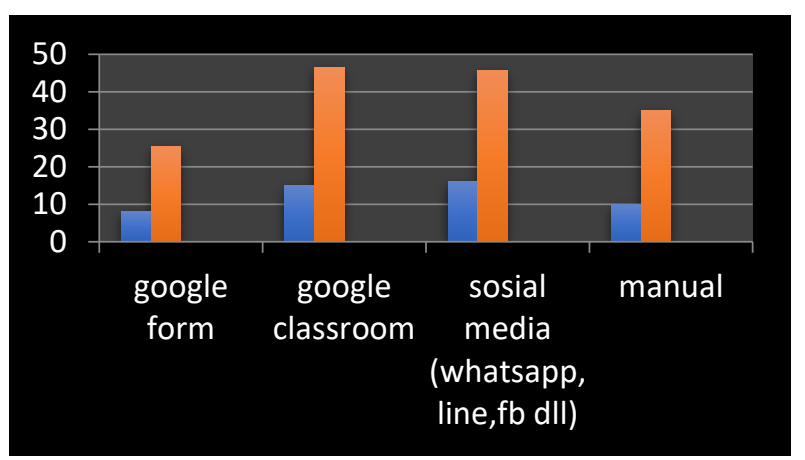

Diagram 3. The use of learning media application in Junior High School

Based on the diagram above, there are $25,36 \%$ teachers using Google Form, 46,54\% Google Classroom, 45,6\% Wahatsapp application and 35\% using the manual method by collecting the assignment to the school. This information was collected through questionnaire filled by every teacher in the junior high school. So, it can be concluded that the use of application media by junior high school teachers puts google form with the highest percentage of use. Some junior high school with internet connection could do the learning via google classroom but for those which do not have the internet connection could not do that so they chose the manual method.

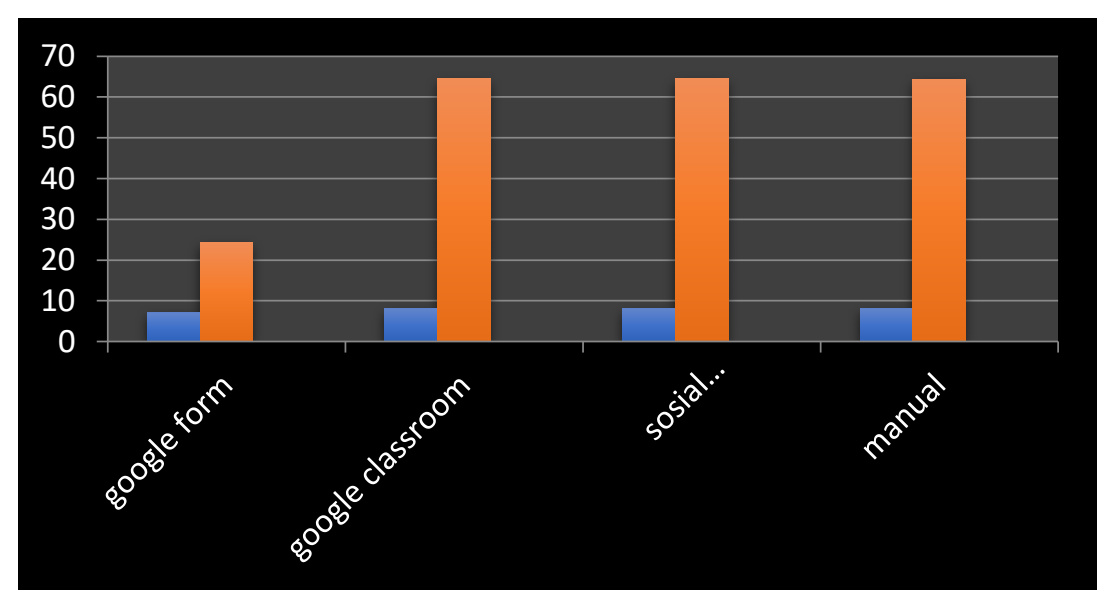

Diagram 4. The use of learning media application in Senior High School

Based on the diagram above, there are 24,42\% Google form, 64,46\% Google Classroom, 64,47\% Social Media Whatsapp, dan 64,42\% manual technique. Therefore, it can 
be concluded that junior high teachers use the application media equally potential among the use of Whatsapp, google classroom and manual. In the online learning process, the teachers' ability in using the application to students' learning where the schools provide the facilities is so important [14]. The geographic location and teachers ability also affect the benefits and the use of media in the learning process. Below is the graphic of the use of learning media by the physical education teachers:

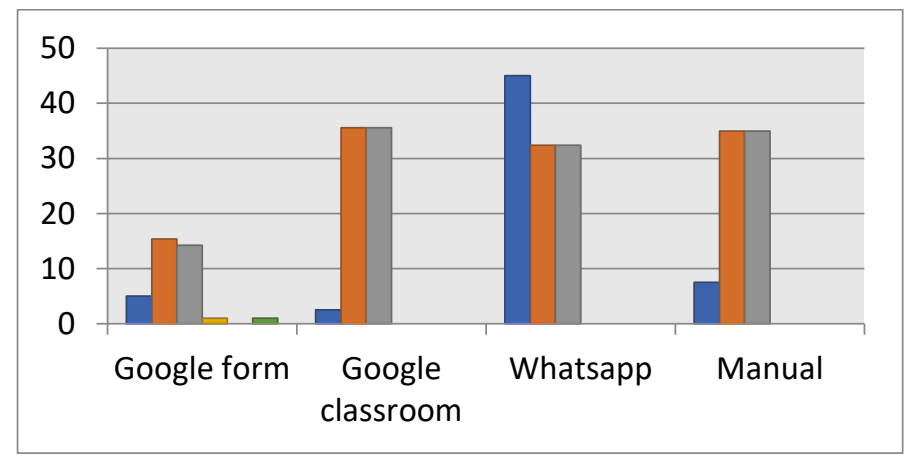

Diagram 5 . The use of learning media by the physical education teachers

Based on the data presented above, the physical education teachers in elementary school aged 24-40 very often use the Whatsapp (45\%) while the teachers aged 40 above (49 $\%$ ) belong to the high level category. The teachers in junior high school aged 24-40 often uses the media of google classroom $(35,54 \%)$ and teachers aged 40 above $(34,32 \%)$ belong to the high level category. Meanwhile, teachers in senior high school aged 24-40 equally use three media, namely, google classroom (35,54\%), Whatsapp 32,43\% and manual 35\%. While for teachers aged 40 above, they belong to the high level category $(30,33 \%)$. Therefore, it can be concluded that the use of social media Whatsapp tends to be used by teachers of elementary school, and then the use of google classroom tends to be used by junior high school teachers and the equal use of google classroom, Whatsapp and manual technique by teachers in the senior high school [15].

Based on the result above, it can be concluded that the online learning being done by teachers in Landak Regency from educational units (elementary, junior and senior high school) on the use of application media and the age of teachers shows that it is so varies in the outmost area. Therefore, the conclusion is that the application media use by teachers during the pandemic which is very new for them is effectively used by teacher in their own house. Many people think that the online learning is not effective, but, in fact, it is now held by teachers and students during the pandemic. Some applications can be used during the pandemic, namely, Whatsapp, Youtube, Telegram, google classroom, and google form. Whatsapp is one of the applications used widespread by teachers because of the easiness to use it. Nevertheless, in the outmost area, it is so difficult to access all the applications because of the internet connection, teachers and students limitation in operating and also owning the supportive devices required, and the other factors. There is also a manual technique where 
students take the assignment in the school and bring it back to school later on [16]. Although, there are also some teachers living in the strategic area can make use of google classroom.

\section{Conclusion}

Based on the research having been done by researcher, it can be concluded that every teacher especially physical education teacher must be able to prepare and be ready to face any changes from the current situation. Teachers are required to have competency to adapt the development, be update to the current information technology, and not be dependent to the current situation around them. That suggestion, without any exception, goes the same way to the physical education teachers in the outmost area. They should keep working and learn to take some benefits from the technology to be applied in the learning process because to give up on the bad situation is not the solution that can be given to our students. Teachers should be responsive toward the technology development and always try to develop so they can create the academic environment which is active, creative, humanist and solutive.

\section{References}

[1]. Imron Rosyadi. (2013) 'COURSE REVIEW HORAY', 2(4), pp. 45-50.

[2]. Anugrahana, A. (2020) 'Hambatan , Solusi dan Harapan: Pembelajaran Daring Selama Masa Pandemi Covid-19 Oleh Guru Sekolah Dasar', pp. 282-289.

[3]. Valensiana Vortunata Ari Ustoyo. (2020) 'Implementasi Pembelajaran Daring Di Sekolah Dasar Islam Dalam Masa', VI(2), pp. 261-271.

[4]. Covid, M. P. (2020) 'Jurnal Utile Implementasi dan Hambatan Pada Pembelajaran Daring Di', VI, pp. 220-225.

[5]. Eskploratif, S. (2020) 'Keuntungan, Kendala dan Solusi Pembelajaran Online Selama Pandemi Covid-19 : Studi Ekploratif di SMPN 3 Bae Kudus Lina Handayani’, 1(2), pp. 15-23.

[6]. Gelar, A. and Sebut, Y. S. (2021) 'Potret Pendidikan di Kalimantan Barat saat Pandemi Covid-19, Radio Jadi Media Pembelajaran', pp. 1-6.

[7]. Guru, P. et al. (no date) 'total sampling', pp. 1-10.

[8]. Murdiyanto, E. (2020) Metode penelitian kualitatif.

[9]. Nadia, O. and Azzahra, F. (2021) 'Ringkasan Kebijakan | Mengkaji Hambatan Pembelajaran Jarak Jauh di Indonesia di Masa Covid-19', pp. 1-9.

[10]. Negeri, S. M. A., Merawan, D. and Medan, N. (2015) ' $=6.596>f^{\prime}, 2(1)$.

[11]. Pembelajaran, H., Irna, P. and Spd, S. (2005) 'Opini 8', (20), p. 95605611.

[12]. Prawiyogi, A. G. and Purwanugraha, A. (no date) 'Efektifitas pembelajaran jarak jauh terhadap pembelajaran siswa di sdit cendekia purwakarta'.

[13]. 'SE no.13 disdikbud tahun 2020 tentang pelaksanaan kebijakan pendidikan dalam masa darurat penyebaran covid.PDF' (no date).

[14]. 'Strategi Pembelajaran, multimedia' (2000), pp. 1-10.

[15]. Teknologi, P., Dan, I. and Tik, K. (2013) 'Untuk Pendidikan Di Daerah Terpencil , Tertinggal , dan Terdepan ( 3T ) Utilization of Information and Communication Technology ( ICT ) for Education In Remote, Undeveloped, and Frontier', 17, pp. 238-245.

[16]. Tuesday, P. (2021) 'E- Learnin g Penjask es ? Mungki’, pp. 1-13. 